\title{
温度眼振検査における刺激法及び観察条件の差の検討
}

$$
\text { 二木 隆 }
$$

\section{Caloric Test Results : A Comparison between the Simplified Method and Electronystagmography}

\author{
Takashi Futaki \\ (Tokyo University)
}

In 48 patients with Ménière's disease, caloric testing was done with $2 \mathrm{ml}$ of ice water and $50 \mathrm{ml}$ of hot water at $44^{\circ} \mathrm{C}$ for $20 \mathrm{sec}$. The simplified method measures the duration of caloric response. With electro nystagmography the maximum velocity of the slow component can be determined.

A statistical comparison showed that the latter test is significantly more sensitive than the former.

Key words : caloric test, duration, maximam velocity, Frenzel's glass ENG

\section{は じめに}

温度眼振検査法については，昭和45年の標準化到がなされているにも拘らず，各施設の方法は色 々である．今回，その再度の標準化のための一資料たるべく，2つの異なる刺激ならびに観察条件 下で温度試験を行ないその相異をしらべたので報告し, 若干の考察を加えた.

方

対象 : 東京大学附属病院耳鼻科を訪れたメ二 エール病を中心とする患者48名で, 男 23, 女25 名で年令は19歳から79歳におよぶ.

方法：これら同一被験者に対して，i）まず, 氷水による「簡便法」（以後, 簡便法と記す） を行った．即ち，アイスバケットの水水をスポ イトにとり $(1.5 \sim 2 \mathrm{cc})$, 注水耳を上になるよ う頸を迴し，15秒間注水 (点耳) し直ちにティ ッシュペーパーで拭きとる. 頭を正中にもどし て, フレンツェル眼鏡下に, 頻度, 持続時間,
法

誘発眩莗のチェックを行なった。代表値は，持 続時間とした。

ii）もら一つの方法は, 暗所開眼下に ENG （原波形は $\mathrm{DC}$, 微分波形は $\mathrm{TC}=0.03 \mathrm{sec}$ ）記 録し, 刺激は, $44^{\circ} \mathrm{C}, 50 \mathrm{cc}, 20$ 秒間の注水とし た.用いたパラメターの代表は, 緩徐相最大速 度とした（以後「ENG 記録」）。これは, 用手 計測で得られた数字である.

この 2 つの検査は, 同一日に施行したもので はない。 
結

48 名に対して施行した 2 つの温度眼振検查の

数值ならびに, 各項の平均值と $\mathrm{SD}$ を示すと表

1 の如くなる.

\section{果}

すなわち，簡便法では患側の持続時間平均值 97.1秒（28.7一カッコ内 SD一), 健側では136 .3秒（27.2）であり，その CP-index は 17.6

表 1

\begin{tabular}{|c|c|c|c|c|c|c|c|c|c|c|c|c|c|c|}
\hline \multirow{3}{*}{ 番号 } & \multirow{3}{*}{ 氏 名 } & \multirow{3}{*}{ 年性 } & \multirow{3}{*}{ 病 名 } & \multirow{3}{*}{ 患 側 } & \multicolumn{6}{|c|}{ 簡便法による温度試験 } & \multicolumn{3}{|c|}{ 暗所開眼 ENG による } & \multirow{3}{*}{ 備 考 } \\
\hline & & & & & \multicolumn{3}{|c|}{ 持続時間（秒） } & \multirow{2}{*}{ 頻 } & \multirow{2}{*}{ 度 } & \multirow{2}{*}{$\begin{array}{l}\text { め屯 } \\
\text { い感 }\end{array}$} & \multirow{2}{*}{$\begin{array}{l}\text { 患 側 } \\
(\% / \mathrm{sec})\end{array}$} & \multirow{2}{*}{ 健 側 } & \multirow{2}{*}{$\begin{array}{l}\text { C P } \\
\text { (\%) }\end{array}$} & \\
\hline & & & & & 患側 & 健側 & $\begin{array}{l}\text { C P } \\
(\%)\end{array}$ & & & & & & & \\
\hline 1 & H.N. & 28 우 & $\mathrm{MD}$ & $\mathrm{L}$ & 80 & 115 & 18 & 118 & 136 & 正 & 9.5 & 14.0 & 21 & \\
\hline 2 & N.H. & 56 우 & $\mathrm{MD}$ & $\mathrm{R}$ & 95 & 198 & 35 & 201 & 278 & 正 & 9.0 & 17.0 & 31 & \\
\hline 3 & K.U. & 64 우 & $\mathrm{MD}$ & $\mathrm{R}$ & 102 & 145 & 17 & 132 & 149 & 逆 & 9.0 & 17.0 & 31 & op \\
\hline 4 & A.T. & 58 今 & $\mathrm{MD}$ & $\mathrm{R}$ & 65 & 108 & 25 & 38 & 121 & 正 & 1.5 & 21.0 & 87 & \\
\hline 5 & B.K. & 48우 & S.H. & $\mathrm{R}$ & 72 & 113 & 22 & 56 & 123 & 正 & 9.5 & 13.0 & 16 & \\
\hline 6 & S.W. & 51우 & S.D. & $\mathrm{R}$ & 121 & 132 & 4 & 155 & 151 & 逆 & 42.0 & 44.0 & 2 & \\
\hline 7 & C.K. & 34 ○े & Iate Hyd & $\mathrm{L}$ & 143 & 106 & -15 & 125 & 85 & 逆 & 8.5 & 17.0 & 33 & \\
\hline 8 & K.S. & 46 우 & S.D. & $R($ (?) & 117 & 134 & 7 & 196 & 201 & 正 & 29.0 & 23.5 & -10 & \\
\hline 9 & S.C. & 19 우 & Iate Hyd & $\mathrm{R}$ & 77 & 117 & 21 & 66 & 88 & 正 & 13.5 & 13.5 & 0 & op. \\
\hline 10 & M.H. & 47 우 & $\mathrm{MD}$ & $\mathrm{R}>\mathrm{L}$ & 91 & 102 & 6 & 125 & 101 & 正 & 9.0 & 10.5 & 8 & \\
\hline 11 & N.K. & 54 우 & $\mathrm{MD}$ & $\mathrm{R}$ & 121 & 173 & 18 & 205 & 263 & 正 & 18.0 & 31.0 & 27 & \\
\hline 12 & Y.S. & 43우 & $\mathrm{MD}$ & $\mathrm{R}$ & 107 & 129 & 9 & 146 & 118 & 正 & 8.0 & 27.5 & 55 & op. \\
\hline 13 & H.C. & 41 우 & $\mathrm{MD}$ & $\mathrm{L}>\mathrm{R}$ & 62 & 114 & 29 & 56 & 189 & 正 & 6.0 & 31.0 & 68 & op. \\
\hline 14 & M. F. & 45 今 & $\mathrm{MD}$ & $\mathrm{R}$ & 80 & 92 & 5 & 46 & 33 & 逆 & 15.0 & 15.5 & 21 & \\
\hline 15 & M. S. & 28 우 & hypo & $\mathrm{R}$ & 57 & 104 & 29 & 86 & 115 & 正 & 35.0 & 47.0 & 5 & \\
\hline 16 & H.N. & $61 \hat{\jmath}$ & S.D. & $\mathrm{R}$ & 63 & 215 & 55 & 64 & 215 & 正 & 21.0 & 23.0 & 5 & \\
\hline 17 & S.M. & 58 우 & $\mathrm{MD}$ & $\mathrm{L}$ & 125 & 138 & 5 & 156 & 188 & 正 & 17.0 & 62.0 & 57 & op. \\
\hline 18 & T.Y. & $53 \hat{\jmath}$ & hypo & $\mathrm{R}$ & 42 & 113 & 46 & 17 & 95 & 正 & 0.0 & 7.5 & 20 & \\
\hline 19 & Y.K. & 65 今 & $M D$ & $\mathrm{R}$ & 110 & 145 & 14 & 90 & 175 & 正 & 5.0 & 21.0 & 62 & \\
\hline 20 & K.S. & 43 & $\mathrm{MD}$ & $\mathrm{L}$ & 92 & 109 & 8 & 86 & 152 & 正 & 7.5 & 22.0 & 49 & \\
\hline 21 & E.M. & 43우 & $\mathrm{MD}$ & $\mathrm{R}$ & 81 & 108 & 14 & 74 & 129 & 正 & 5.0 & 14.5 & 49 & op. \\
\hline 22 & S.Y. & $49 \hat{\jmath}$ & $\mathrm{MD}$ & $\mathrm{L}$ & 151 & 167 & 5 & 157 & 138 & 正 & 57.0 & 80.0 & 17 & op. \\
\hline 23 & M.G. & $38 \hat{\jmath}$ & hupo & $\mathrm{L}$ & 130 & 151 & 7 & 163 & 164 & 正 & 6.0 & 18.0 & 50 & op. \\
\hline 24 & K.M. & 48 今 & $M D$ & $\mathrm{~L}$ & 94 & 127 & 15 & 96 & 147 & 正 & 10.5 & 4.5 & -40 & \\
\hline 25 & I.S. & 56今 & hypo & $\mathrm{L}$ & 112 & 135 & 9 & 124 & 196 & 正 & 6.0 & 13.5 & 38 & \\
\hline 26 & T.M. & 38 우 & $\mathrm{MD}$ & $\mathrm{L}$ & 86 & 115 & 14 & 139 & 186 & 正 & 19.0 & 26.0 & 16 & \\
\hline 27 & G.H. & 60 응 & hypo & L & 165 & 185 & 6 & 196 & 185 & 逆 & 6.0 & 13.0 & 37 & \\
\hline 28 & I. K. & 79 今 & $\mathrm{MD}$ & $\mathrm{R}$ & 58 & 115 & 33 & 26 & 122 & 正 & 5.5 & 3.5 & -22 & \\
\hline 29 & T. T. & 42 우 & $\mathrm{MD}$ & $\mathrm{R}$ & 83 & 152 & 29 & 32 & 136 & 正 & 21.0 & 38.0 & 29 & \\
\hline 30 & M. S. & 49ई & MD & $\mathrm{L}$ & 155 & 192 & 11 & 221 & 225 & 正 & 38.0 & 43.0 & 6 & \\
\hline 31 & Y.T. & 46今 & $\mathrm{MD}$ & $\mathrm{R}$ & 108 & 133 & 10 & 152 & 171 & 正 & 17.0 & 25.0 & 19 & \\
\hline 32 & K.W. & 57 今 & $M D$ & $\mathrm{~L}$ & 115 & 140 & 10 & 142 & 122 & 正 & 4.5 & 10.0 & 38 & \\
\hline 33 & K.R. & 54 우 & $\mathrm{MD}$ & $\mathrm{L}$ & 85 & 113 & 14 & 60 & 113 & 正 & 4.0 & 22.0 & 69 & op. \\
\hline 34 & U.G. & 56今 & $M D$ & $\mathrm{~L}$ & 140 & 152 & 4 & 159 & 162 & 正 & 11.0 & 19.0 & 27 & \\
\hline 35 & S.T. & $31 \hat{\delta}$ & $\mathrm{MD}$ & $\mathrm{L}$ & 125 & 145 & 7 & 97 & 148 & 正 & 6.6 & 8.5 & 17 & op. \\
\hline 36 & K.S. & 73 우 & $M D$ & $\mathrm{R}$ & 97 & 145 & 20 & 68 & 230 & 正 & 13.0 & 18.0 & 16 & \\
\hline
\end{tabular}


表 1 - 2

\begin{tabular}{|c|c|c|c|c|c|c|c|c|c|c|c|c|c|c|}
\hline \multirow{3}{*}{ 番号 } & \multirow{3}{*}{ 氏 名 } & \multirow{3}{*}{ 年性 } & \multirow{3}{*}{ 病 名 } & \multirow{3}{*}{ 患 側 } & \multicolumn{6}{|c|}{ 簡便法による温度試験 } & \multicolumn{3}{|c|}{ 暗所開眼 ENG による } & \multirow{3}{*}{ 備 考 } \\
\hline & & & & & \multicolumn{3}{|c|}{ 持続時間（秒） } & \multirow{2}{*}{ 頻 } & \multirow{2}{*}{ 度 } & \multirow{2}{*}{$\begin{array}{l}\text { めま } \\
\text { い感 }\end{array}$} & \multirow{2}{*}{$\begin{array}{l}\text { 患 } \quad \text { 側 } \\
(\% / \mathrm{sec})\end{array}$} & \multirow{2}{*}{ 健 側 } & \multirow{2}{*}{$\begin{array}{l}\text { C P } \\
(\%)\end{array}$} & \\
\hline & & & & & 患側 & 健側 & $\begin{array}{l}\text { C P } \\
(\%)\end{array}$ & & & & & & & \\
\hline 37 & S.R. & $32 \hat{\jmath}$ & $\mathrm{MD}$ & $\mathrm{L}$ & 132 & 160 & 10 & 86 & 149 & 正 & 10.0 & 29.0 & 49 & op. \\
\hline 38 & K. S. & 67 우 & $\mathrm{MD}$ & $\mathrm{R}$ & 78 & 135 & 28 & 44 & 120 & 正 & 19.0 & 27.0 & 17 & \\
\hline 39 & I. K. & $33 \hat{\jmath}$ & $\mathrm{MD}$ & $\mathrm{R}$ & 76 & 137 & 29 & 58 & 168 & 正 & 8.0 & 25.0 & 52 & \\
\hline 40 & K. T. & 48 우 & $\mathrm{MD}$ & $\mathrm{L}$ & 97 & 180 & 30 & 112 & 193 & 正 & 8.0 & 17.0 & 36 & \\
\hline 41 & K.N. & 57 우 & $\mathrm{MD}$ & $\mathrm{L}$ & 113 & 138 & 10 & 127 & 147 & 正 & 7.0 & 15.0 & 36 & \\
\hline 42 & E.A. & $29 \uparrow$ & $\mathrm{MD}$ & $\mathrm{L}$ & 105 & 145 & 16 & 73 & 191 & 正 & 17.0 & 15.5 & -5 & \\
\hline 43 & I. K. & 37 우 & S.D. & $\mathrm{R}$ & 70 & 143 & 34 & 42 & 167 & 正 & 5.0 & 36.5 & 76 & \\
\hline 44 & T. A. & 62 우 & $\mathrm{MD}$ & $\mathrm{R}$ & 93 & 155 & 25 & 182 & 296 & 正 & 6.5 & 28.0 & 62 & op. \\
\hline 45 & K.N. & 44 우 & $\mathrm{MD}$ & $\mathrm{R}$ & 48 & 131 & 46 & 23 & 167 & 正 & 8.0 & 18.5 & 40 & pp. \\
\hline 46 & Y.C. & 30 우 & $\mathrm{MD}$ & $\mathrm{L}$ & 97 & 116 & 9 & 125 & 236 & 正 & 9.0 & 32.0 & 56 & \\
\hline 47 & U.H. & $47 \hat{\delta}$ & $\mathrm{MD}$ & $\mathrm{R}$ & 83 & 123 & 19 & 69 & 108 & 正 & 13.0 & 35.0 & 46 & \\
\hline 48 & T.M. & $52 \hat{\jmath}$ & $\mathrm{MD}$ & $\mathrm{L}$ & 62 & 104 & 25 & 53 & 130 & 正 & 6.5 & 17.0 & 45 & \\
\hline $\begin{array}{c}\mathrm{X} \\
\mathrm{S} \mathrm{D}\end{array}$ & & & & & $\begin{array}{l}97.1 \\
28.7\end{array}$ & $\begin{array}{r}136.3 \\
27.2\end{array}$ & $\begin{array}{l}17.6 \\
13.0\end{array}$ & & & & $\begin{array}{l}13.0 \\
10.9\end{array}$ & $\begin{array}{l}22.9 \\
14.2\end{array}$ & $\begin{array}{l}30.5 \\
25.7\end{array}$ & \\
\hline
\end{tabular}

MD : $x=$ エール病 S. D. : 突発性難聴

late Hyd : 遅発性内リンパ水腫 S. H.: 梅毒性内リンパ水腫

Hypo：末梢性迷路機能低下症

\%（13.0）であった.この際, 頻度は fidelity に乏しいので比較の項目とはしなかった，誘発 された眩量が，健側でより強かったものを正と

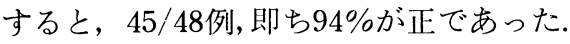

一方 ENG 法では, 患側の緩徐相最大速度 の平均は $13.0^{\circ} / \mathrm{sec}(10.9)$ であるのに比して, 健側のそれは $22.9^{\circ} / \mathrm{sec}$ (14.2) でその CP-index は30.5\% (25.7) であった.

CP の処で(一)を附したのは, 健側の方が反応 の低いもので, 前者の方法で 1 例, ENG 法で は 4 例 $(8 \%)$ になった.

この簡便法での持続時間の各々と, ENG 法 での最大速度の両者に有意差があるか否か検定 すると，表 2 に示す如く，対応をとるかとらぬ か 2 つのり方でも, 夫々, 平均值において有 意な差のあることが示された。

すなわち，2つの方法により得られた患側と 健側の反応の差, 或いは勾配は, 有意の差をも つ異なったものであることが示された．最大速
度 $(\mathrm{ENG})$ 法の方がより鋭敏にその勾配を示す が，バラッキも大きいことが示され，似つかわ しい傾向を示すが，診断学的に 2 つ検查から の左右美は「等価值」のものではないといえる.

表 2

対応のある平均值の比較

$$
\left\{\begin{array}{l}
\mathrm{t}=3.088 \\
\mathrm{p}<0.01
\end{array}\right.
$$

対応のない平均值の比較

$$
\left\{\begin{array}{l}
\mathrm{F}=3.905 \\
\mathrm{t}=3.088 \\
\mathrm{p}<0.01
\end{array}\right.
$$

表 2 をまとめて図示すると図 1 の如くなり, 患側, 健側の高さの差は ENG の方が大きい が，バラつきは簡便法の方が少ない。これは, CP-index を比較した図 2 に於いて，一そうそ らした傾向がよくよみとれる。 


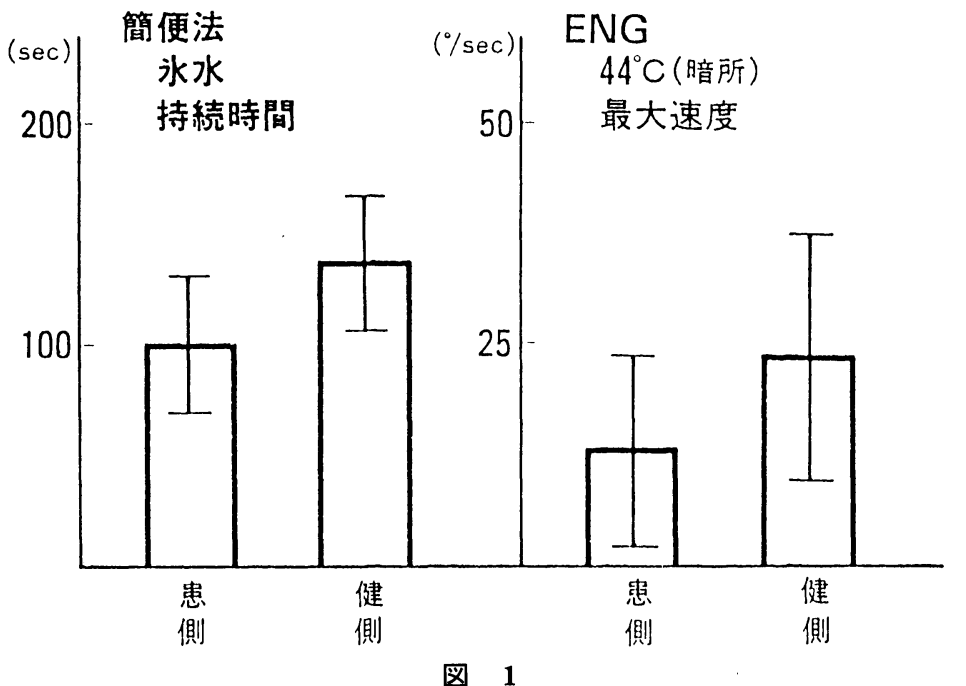

誘発眩量の $94 \% か ゙ ，$ 簡便法において（正）だ ったことは，本法において，「どちらがつよく まわりましたか」と問らことの重要性を物語っ ているといえよう。

なお，表1において患側闌に $\mathrm{R}>\mathrm{L}$ とある のは，両側例で大きい方が先行耳である.

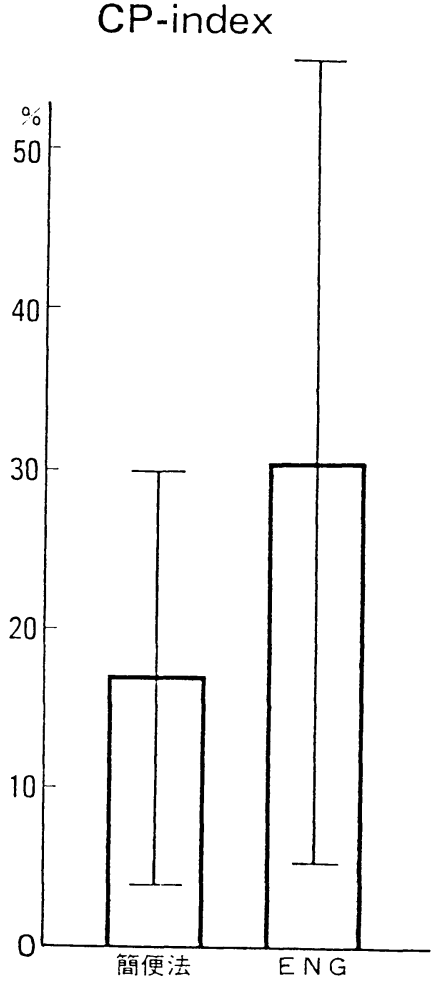

図 2
考

1909年の有名な論文の中で Bárány ${ }^{2)}$ は「Schmiedkam（1868）が，自分を実際に供してこ の現象を最初に発見した人である，彼は，鼓膜 に $117 \mathrm{~cm}$ の高さの冷水柱で荷重したら, 強い 疼痛, めまい, 悪心, 失神, 嘔吐が拈きた」と 書いている.

何れにせよ Bárány によって温度眼振は生理 学上, 内リンパ運動説によって不動の地位を占 めたものといえる.「迷路内容物の直接の部分 的な冷却，または温度と，それによってひきお こされる内淋巴運動が存在する, といら仮定が 私にはもっともあり得べきことのように思われ るからである」「眼振の方向に関する頭位の依 存性は, 注入水の温度と頭の位置によって確実 にきまることがわかった」（村主好弘訳）と喝 破している.

\section{按}

Bárány 法は $120 \mathrm{cc}$ 以上の，大量法といえる が Kobrak $(1923)^{3)}$ は, 5 cc の $5{ }^{\circ} \mathrm{C}$ 違いの minimal syring ng を提唱した. これに反対し た Schmaltz $(1932)^{4)}$ は，温度勾配と内リンパ 流についての 数学的な検討を加光, Steinhausen $(1929)^{5)}$ のクプラの偏位した写真と相俟っ て，いずれにせよ cupular deflexion が温度 眼振発生の mechanism と考えられている.

諸家により，例えば Atkins $(1939)^{6)}$ 法では 東大もこれに追随しており，本論文の「簡便 法」となっているが……，いろいろの方法がい われたが，決定的ともいえる報告は言らまでも なく, Fitzgerald and Hallpike (1942) ${ }^{7)}$ によ る冷温交互刺激法であるといえる，注水温はむ やみに熱くはできないし，また冷たければよい というものではない，体温との差が最小でか 
つ, 最大の変化量を眼振にて観察できる点は, 温度一反応曲線に打ける変曲点であり，これは $37^{\circ} \mathrm{C}$ を体温としたときの $\pm 7{ }^{\circ} \mathrm{C}$ であるとし た。これによって冷温交互試験を両耳に行ら方 法が確立されたといってよい. Hallpike（19 43) ${ }^{8)}$ は，それを持続時間で記載して有名なカ ロリグラムを考案している. 原法は天井注視で $250 \mathrm{cc}$ 近くの大量を 30 秒で注入する（Rubin 1968) ${ }^{9)}$ 方法であるが Jongkees ${ }^{10)}$ は 1948年, 温度眼振検查法の standard のない事を冒頭に 挙げながら60名の医学生を用いた論文を発表し ている，彼の方法は頭を背位より $30^{\circ}$ 挙上し， Frerzel 眼振鏡装着下に観察し, 注水方法は, $30^{\circ} \mathrm{C}$ の水 $50 \mathrm{cc}$ から注入 (秒数の記載なし) す る. 次いで $44^{\circ} \mathrm{C}$ に移る. 持続時間を要素とし て CP・DP の基準を 20\%にとった彼の結果は, 47 名 $/ 60$ 例 (78\%) は正常範囲内であった。残り
の13例（22\%）は CP または DP であるが， $\mathrm{CP} 3$ 例のらち 2 例は家族歴にメニエールや喘 息があり，CP で正常は 1 例にすぎないとして いる(1.6\%).17\%，10例は DP で右向き 2 ， 左向き 8 例であったとしている．右利きの大脳 半球優位性とか, 耳石系とか, 血管性要素とか につき詳しく論及しており，血管性要素，特に 外耳道を介しての反射を証明する為に外耳道の 麻酔をしてからの注水等, DP の謎に迫る優れ た知見を述べており，興味のある方には一読を 勧めたいものである. 日本平衡神経科学会の標 準化が以前（1970）行われたが，その時 $20 \mathrm{cc}$, 20秒注水ときまって了った．20秒は良いとして も，20 cc をチビチビ入れるのはかなりむつか しい. 少なくとも $50 \mathrm{cc}$ ないと水流を一定に保 てないきらいがあるといえよう。

Frenzel 眼振鏡下での持続時間の観察が sc-

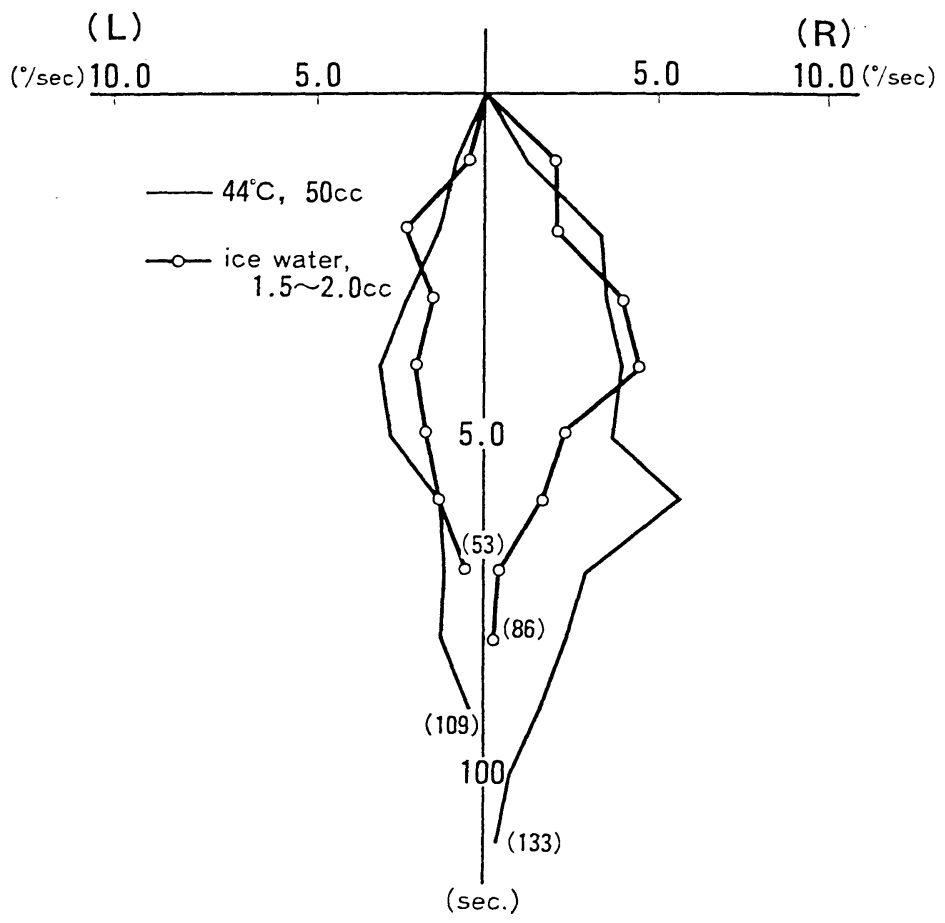

図 3 両者の比較をした 1 例（カッッコ内は打数） 
reening test に座を移さざるを得なくなったは 言らまでもなく，眼振電計 (ENG) の登場で ある，温度眼振の記録については，画期的な業 績として Henriksson (1956) ${ }^{11)}$ の論文がある. 「同様の刺激が用いられた場合は，持続時間の 方が最大眼球速度より定常性がある. しかしな がら，刺激の強さを上げていくとき，その数值 に対応した反応を示すのは最大速度であって持 続時間は大して変動しない. 後者は反応の硬直 性の表現と考えられ, 眼球速度は感覚機構の刺 激に対する反応に怙ける興奮性の正確度が高い
ものと考えられる」と記載されており，この事 は現在も定説となっている. 彼の報告は Hinchcliffe $(1967)^{13)-14)}$ の 3 つの論文によって数学 的な分析に基づいて確認され, さらに最大速度 のらちでも暗所開眼での $44^{\circ} \mathrm{C}$ のものが一番迷 路の興奮性を正確に表現するものであり, 頻度 や誘発眩量感等は他の要素の修飾をうけてしま らものと指摘している. この $44^{\circ} \mathrm{C}$ の優位説は Barber ら (1971) $)^{15)}$ によって冷温両方からの CP-index と $44^{\circ} \mathrm{C}$ 単独でのそれは0.76の相関 で最高值であったと報告されており，また，国

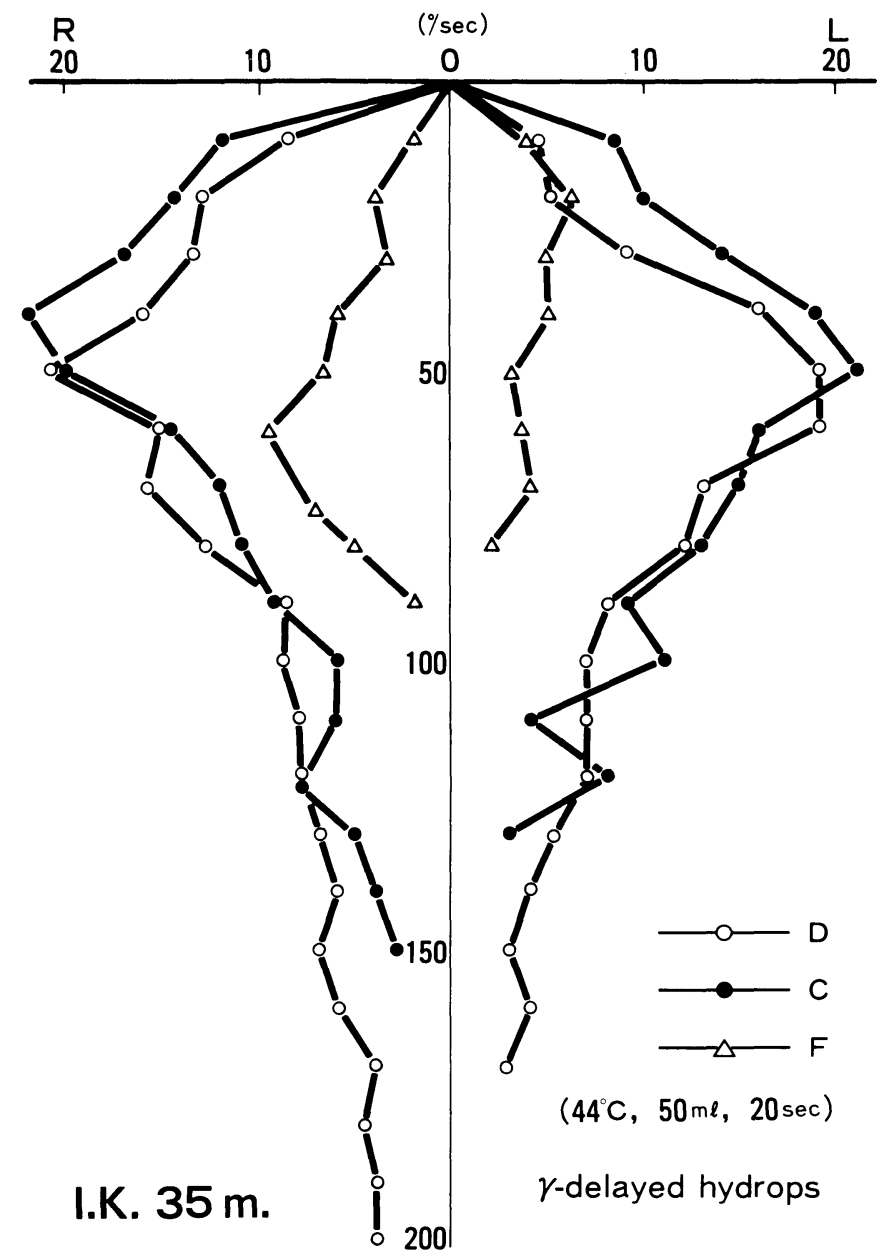

(sec)

図 4 暗所開眼 (D), 閉眼 (C) およびフレンッェル鏡（F）で行った温度反応 
立病院めまい班研究（班長：高安劭次）によっ ても全国的に施行された結果は $44^{\circ} \mathrm{C}$ の方が良 いと出つつある. 冷温交互試験は時間を喰らの でどちらかを省きたいと考劣る場合に，これら の仕事は大いに参考になるといえる.

ENG の記録で問題となるのは閉眼か暗所開 眼かといらことであるが，これは言らまでもな く, 前者では Bell 現象で眼球は上転してしま らし, suppression がかかってしまうし，一定 の alertness を維持できて, 打ち方の constancy の良い後者に軍配が上がる．やむなく閉眼
とする場合でも，Gillirgham (1969) ${ }^{16)}$ の言う ごとく暗算負荷または backward counting が, そらでない場合より有意に反応を良好にさせる ことを念願に置かなくてはならない。

CP 側を予測できる指標はないか検討したの は Smith and Barber (1969) ${ }^{17)}$ で, 自発や頭 位眼振よりも，純音聴力低下や語音の方が良く 相関するという興味ある報告をしている。この ことは, 蝸牛症状の無い回転性眩暈で末梢と思 われるものに, もし, 自発または頭位眼振をみ ても，それだけで決して患側を診断できないと

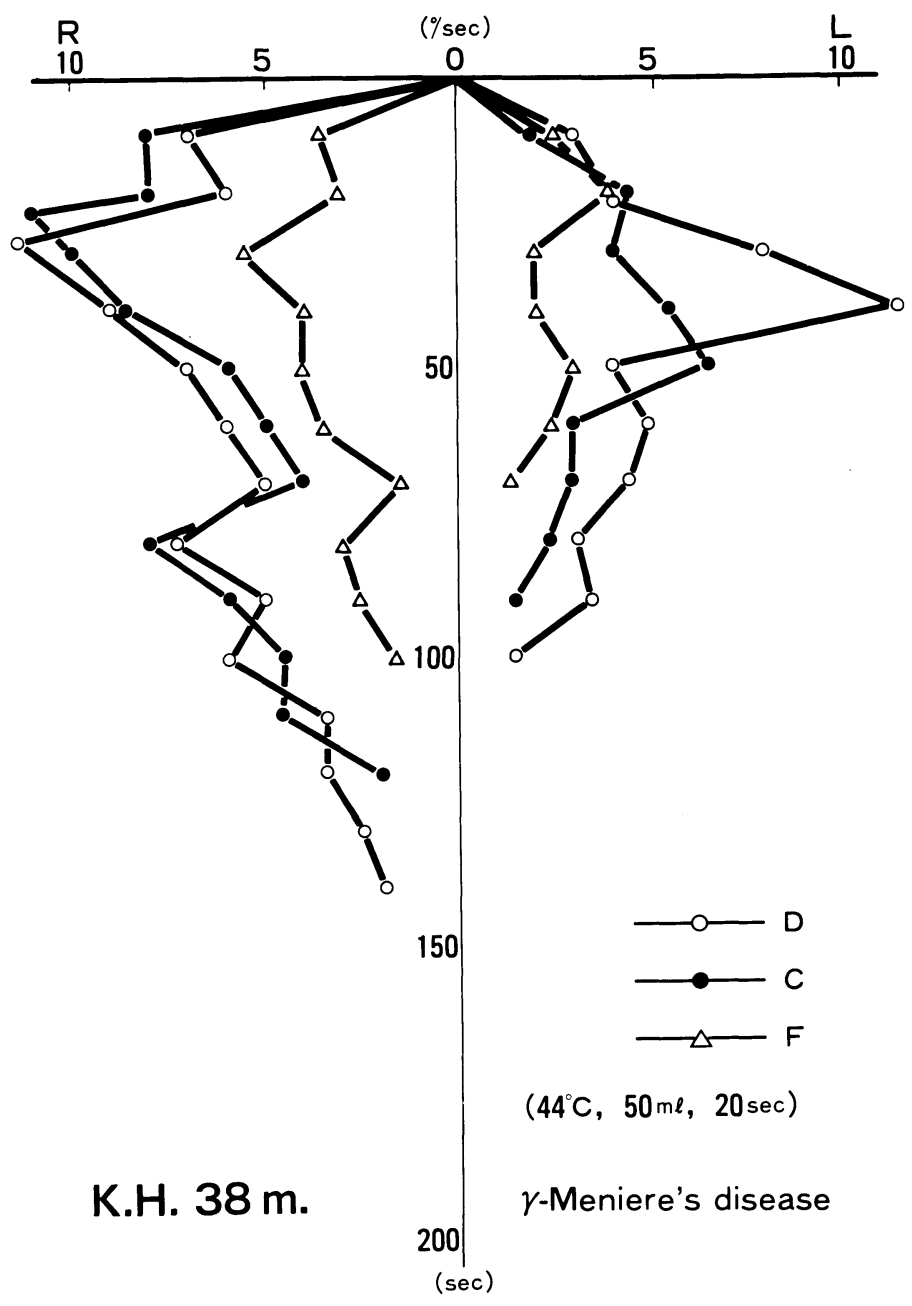

図 5 暗所開眼 (D), 閉眼 (C) およびフレンッェル鏡 $(\mathrm{F})$ で行った温度反応 
いう事を証拠立てている．温度試験を行っては じめて，患側を決めらるのである，言らまでも なく, 生理的刺激である回転試験は, 両耳が刺 激されてしまい，Ewald の法則から脱脚でき ない。「患側はどちらか」といら事に直接答え るのは，今の処，カロリックしかない。しか も，この検査は現在のところ耳科医によってし か行われていない，逆にいらならば，カロリッ クテストも行わずに，何の甲斐あつて耳鼻科か ということになる，要は，これを行ったか否か にある，すなわち，行っていない場合は何の弁
解もできない，重ねて言えば，どのような方法 を採るかは二の次の事である.

さて，そうはいっても，その刺激で，どらい った観察法がよいかは，いろいろ議論の分れる 処であり，又，スクリーニングでよいのか研究 的にやるのかといった「目的」によっても選択 されなくてはならない，著者は ${ }^{18)}, 1983$ 年耳鼻 と臨床に，本シリーズの前身として15例の比較 を同様に行なったが，このときは $\mathrm{t}$ 検定で10\% でも，差がないと出た。しかし，今回の結果と 比較すると，あれは，「例数が少ないので有意

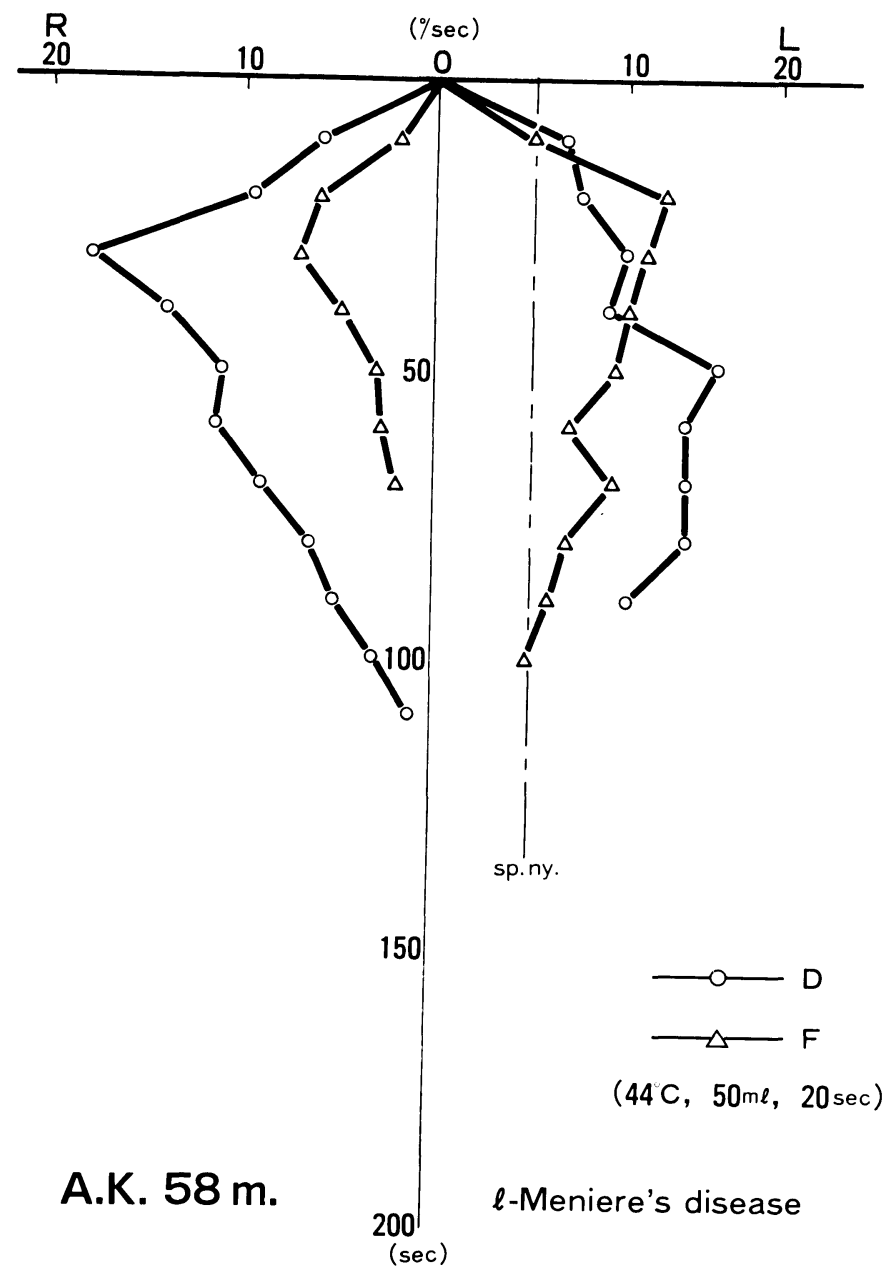

図 6 自発眼振（左向き: $5^{\circ} / \mathrm{sec}$ ）のある症例での温度反応 
差をいえない」といら意味であったと解釈せざ るを得ない。

暗所開眼の $\mathrm{ENG}$ 法と, 簡便法とを $\mathrm{ENG}$ で夫々記録して，その緩徐相や打数をプロット してみると図 3 の如く，比較的並行して，すな わち，速度でも持続時間でも 打数でも，左の hyporeaction の共通してよみとれるものもあ る.

しかし, 次の 3 例では, 暗所開眼, 閉眼お よびフレンツェル鏡の三者に対して, 左右も含 めてランダムに割りつけ，しかも，刺激は皆 $44^{\circ} \mathrm{C}, 50 \mathrm{ml}, 20 \mathrm{sec}$ と同一にして記録してみ た.

I. K. 例（図 4 ）では, 暗所開眼と閉眼は, 殆ど等質の反応経過であることがよみとれる が，フレンツェルでは，はるかに反応は suppress されて了う，そしてこれは，速度でも，持 続時間でもいえる.

図 5 の K. H. 例では, 右では, 暗所も閉眼 も類似の経過を示すが，左耳では，閉眼で suppression がかかって了い, 最大速度で差が出 て了ったのが観察される．勿論フレンッェル鏡

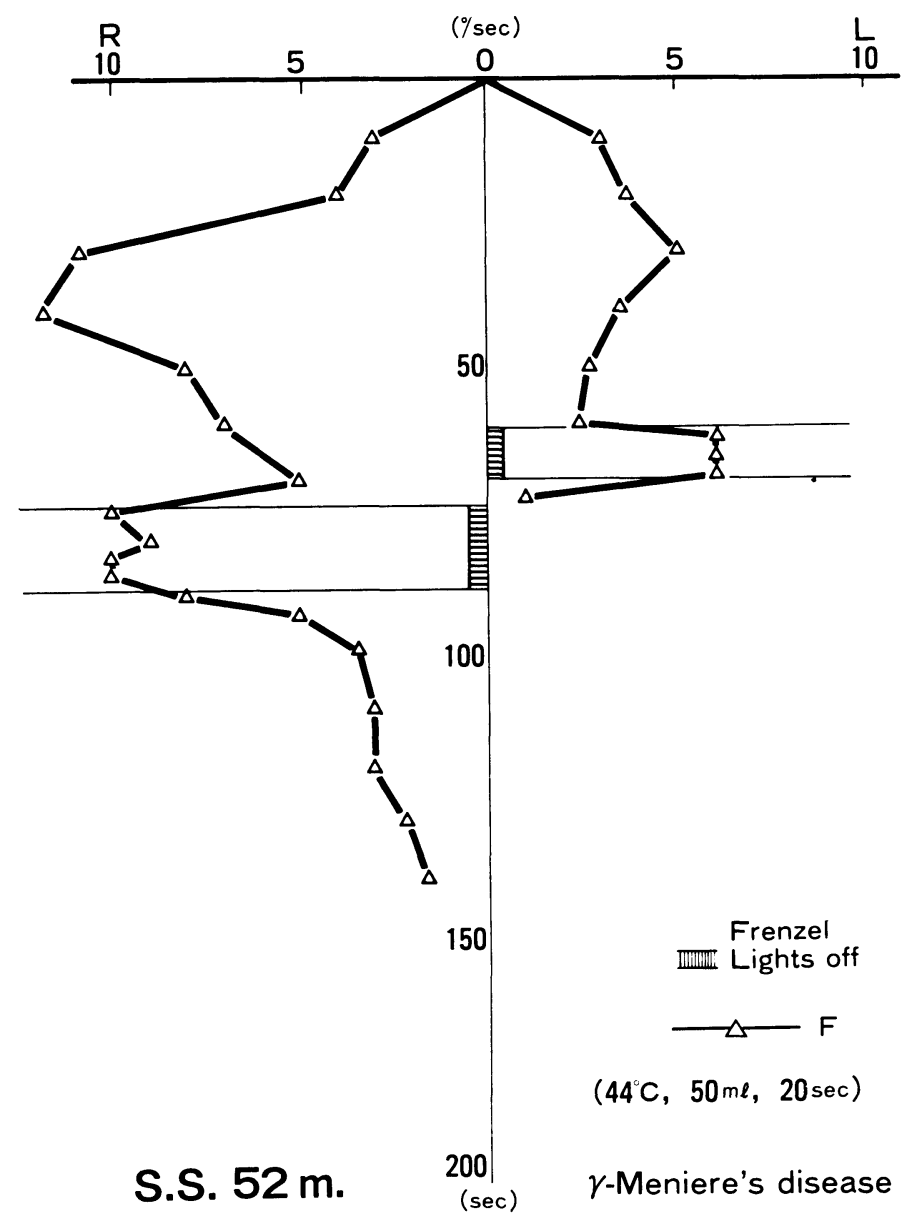

図 7 フレンツェル鏡の豆球を消したときの温度反応（Frenzel-suppression） 
では速度も持続時間も抑制されて了らのがよく 示されている。

自発眼振のある症例では如何かとみると, 図 6, A. K. 例にみる様に, 左向き，5\% 5 sec に O軸移動してみればよい訳で，速度における 1-CP は言えるが，フレンッェル鏡の持続時間 には自発眼振が重なっているのみよみとれる。 この O軸移動は Aschan がきれいに図示して いる.

図 7 の S. S. 例の如く, フレンッェル鏡の豆
球を消す，すなわち暗所開眼，とどうなるか みると倍近い反応の 跳躍がみられる。これは Visual suppression の逆をみている訳であって， Frenzel suppression とでもいいたくなる現象 で興味深い.

いら゙れにせよ，このように，刺激する水の量 や温度もさることながら，「視性条件」の差に よる反応の相異は大きく，暗所開眼にくらべて フレンツェル眼鏡下では，かなりの抑制がかか って了っているものであることがうなづける。

\section{ま と め}

1.メニエール病を中心とした48名の患者に，簡便法と ENG 法を夫々行なって，前者は持続時 間，後者では最大速度をパラメーターとして比較した。

2. 対応の有無に拘らず，平均値の比較では有意差 $(\mathrm{p}<0.01)$ が示された.

3.すなわち，2つの検査から得られた勾配は，診断学的に等価值のものではないことが示された.

4. 前者より後者の方が傾きは大であるがバラつきも大きい.

5. 前者に拉ける「誘発眩量」は94\%にて健側で強かった.

6.フレンツエル鏡下で視性抑制はかなり大なるものがある.

7. 温度眼振検査について若干の文献学的考察を加えた。

本研究は文部省綜合研究「平衡機能検査の基準化並びに診断学的貢献度」（班長 : 朴沢二郎）の費用によった.

\section{文献}

1) Equilibrium Res, vol 26, 1970.

2) Bárány R: Untersuchungen über den vom Vestibularaparatus des Ohres reflektorisch ausgelösten rhythmischen Nystagmus und seine Begleiterscheinungen. Mschr Ohrenhkde 40: 193〜297，1906. (村主好弘，視神経耳科のために)

3 ) Kobrak F : Passow-scdäfers Beirage. XIX 321, 1923.

4) Schmaltz G: The physical phenomena occuring in the semicircular canals during rotatory and thermic stimulation. Proc Roy Soc Med 25: 359 381, 1932.

5 ) Steinhansen W : Folia Otol 57 : 410, 1929.

6) Atkins : 猪初男「耳鼻咽喉科学」より。

7 ) Fitzgerald E and Hallpike CS: Observations on the directional preponderance of caloric nystagmus. Brain 65: 115, 1942.
8) Hallpike CS: The lnvestigation of Meniere's disease. J Laryng 58 : 349, 1943.

9 ) Rubin S: Nystagmography. Arch Otolaryngol 87: 266, 1968.

10) Jongkees LBW : Value of the caloric test of the labyrinth. Arch Otolaryngol 48:402, 1948.

11) Henriksson NG: Speed of slow component and duration in caloric nystagmus. Acta Otolaryngol suppl 125 : 1 39, 1956.

12) Hinchcliffe $R$ : Nystagmus rate as an index of caloric test response. Acta Otolaryngol 65: 311, 1968.

13) Hincheliffe $R$ : Normal volues for caloric test using Electrooculography. J Laryng 81: 221, 1967.

14) Hinchcliffe $R$ : Subjective magnitude of indu- 
ced vertigo as an index of caloric response. J Laryng 81: 875, 1967.

15) Barber HO : Wright $G$ and Demanule F : The hot caloric test as a clinical screening device. Arch Otolaryng 94: 335, 1971.

16) Gillingham KK.: Mental arithmetic during electronystagmographic testing. Ann Otol 78: $3 ; 575,1969$.
17) Smith $\mathrm{DM}$ and Barber $\mathrm{HO}$ : Are caloric test necessary? Ann Otol 78: 950, 1969.

18）二木 隆：カロリック・テスト一気の重い検査一. 耳鼻 $29: 1 ； 127,1983$.

/別刷請求先 : 二木 隆 干113 東京都文京区本郷7-3-1 東京大学医学部耳鼻咽喉科学教室) 